\title{
Selvhjelpsgrupper mot rusavhengighet
}

\author{
Rusavhengighet er en lidelse som krever langvarig behandling og godt samarbeid. Selvhjelpsgrupper kan \\ bidra til å løse noen kontinuitetsproblemer, men egner seg ikke for alle ruspasienter. Selvhjelpsmetodikken \\ er basert på prinsipper som kan styrke behandlingen av rusmiddelavhengige generelt.
}

\section{Trond Nergaard Bjerke}

trond.nergaard.bjerke@unn.no

Fag-og forskningssenteret

Nordnorsk psykiatrisk forskningssenter

Universitetssykehuset Nord-Norge

På tross av rusfagfeltets retorikk om at rusavhengighet er en kronisk lidelse, gjenspeiles ikke det i de intervensjonene som settes inn. Det meste av rusbehandlingen som drives i dag, organiseres og drives som akutt, støtvis, tidsavgrenset innsats med en start og en stopp (1). Også langvarige behandlingsformer, der dette fremdeles eksisterer, kan sies å være lengre versjoner av den samme syklusen med vekt på adgang til behandling, stabilisering, reparering og utskrivning, der pasientene i en kortere periode kan delta $i$ et ettervernsopplegg. Den grunnleggende ideen synes å være at rusavhengighet kan kureres hvis vi bare finner de rette terapeutiske metodene og den rette lengden og intensiteten på innsatsen.

For å få til kontinuitet $\mathrm{i}$ behandlingen av ruslidelser trengs det større vekt på modeller med et langsiktig perspektiv, der det er god overlapping mellom de løpende og de vedvarende innsatsene.

\section{Selvhjelpsgrupper en løsning?}

Som en mulig løsning på kontinuitetsproblemet er bruk av 12-trinns selvhjelpsgrupper som dem Anonyme Alkoholikere (AA) og Anonyme Narkomane (NA) benytter, blitt trukket frem som en nyttig, men for lite brukt ressurs i Norge (2). Selvhjelpsgruppene representerer et langsiktig og lett tilgjengelig tilbud til rusmiddelavhengige - ikke bare som en type ettervern etter annen behandling, men også som et aktuelt tiltak mens man venter på behandling (3). Det er flere kontroverser og mulige årsaker til at selvhjelpsgrupper ikke utnyttes i større grad enn de gjør her i landet, bl.a. manglende kunnskap om hvordan gruppene virker og hva det er som virker (3).

Hensikten med denne artikkelen er å redegjøre for de virksomme faktorene i selvhjelpsmetodikken, slik det praktiseres i 12-trinns selvhjelpsgrupper i organisasjoner som AA og NA.

\section{Rehabilitering er «smittsomt»}

Studier har vist at hvis man tilbringer mer tid sammen med mennesker som ikke ruser seg eller har klart å rehabilitere seg fra rusavhengighet, har man større sjanse for å lykkes i sin egen rehabilitering (4).

Denne typen forskning har bidratt til ny forståelse av de beskyttende mekanismene som gode sosiale relasjoner og et rusfritt miljø kan ha for personer som er i en rehabiliteringsfase (5). Det nærmeste man kommer slike rusfrie sosiale fellesskap i dag er 12-trinns selvhjelpsgrupper som AA og NA.

\section{Selvhjelpsmetodikken}

Basis for selvhjelpsmetodikken er enkeltmedlemmenes erfaringsbaserte kunnskap (6), en kunnskap som er tilegnet gjennom livserfaringer om det å leve som rusavhengig over lang tid. Den er derfor konkret og unik ved at den er knyttet til enkeltpersoners subjektive erfaringer og opplevelser som rusavhengig. Men selv om erfaringsbasert kunnskap er unik og subjektiv, gir den likevel mulighet for gjenkjennelse av noen generelle trekk hos andre og dermed også for en mulighet til å skape mening for andre enn seg selv.

Virkemidlet som brukes for å muliggjøre gjenkjennelse, identifisering og etablering av en felles mening i selvhjelpsgruppene er deling av personlige historier. Dette praktiseres i de lokale AA- og NA-gruppene. Det typiske fortellerformatet er beskrevet som en slags narrativ metode, som inneholder en beskrivelse av problemet og hvordan man kom frem til en løsning (7). Det å dele sine erfaringer på denne måten innebærer at man blir en betydningsfull historieforteller og meningsbærer i et sosialt fellesskap, hvilket kan være en forløsende opplevelse for mange.

\section{Betydningen av fellesskap og tilhørighet}

I selvhjelpsgruppene er alle likeverdige. Heri ligger også muligens noe av kilden til det som gjør rehabilitering fra ruslidelser til noe som kan «smitte» mellom individer. Ikke som i infeksjon, men som i affeksjon ved at man tilbringer tid og yter og mottar hjelp sammen med andre som har det samme målet, nemlig rusfrihet og et bedre liv. Det dannes sterke sosiale bånd mellom medlemmene, hvilket resulterer i en opplevelse av tilhørighet og fellesskap for den enkelte (8). De mellommenneskelige relasjonene representerer også noe kvalitativt annet enn det en pasient-profesjonell-relasjon gjør.

I den sistnevnte relasjonen har pasienten naturlig nok en mer passiv rolle, og det er mindre rom for gjensidighet, likeverd og følelse av fellesskap - pasienten er den hjelptrengende, den profesjonelle eksperten. I selvhjelpsgruppene er problemet både individuelt og felles på samme tid. Dette bidrar også til en destigmatisering av problemet. Å søke hjelp for en ruslidelse er fortsatt en skambelagt handling, men i mindre grad når man søker hjelp hos sine likemenn og -kvinner. Dette fordi man stiller på lik linje med de andre og ses på som en bidragsyter, ikke bare som en passiv mottaker av hjelp.

\section{Gjensidig hjelp og hjelperterapiprinsippet}

Betydningen av gjensidighet og likeverd i selvhjelpsmetoden ivaretas bedre i den engelskspråklige selvhjelpslitteraturen. Der kalles 12-trinns selvhjelpsgrupper for «mutual aid groups». Direkte oversatt blir det «gjensidig hjelp-grupper», hvilket er en mer presis og dekkende benevnelse for disse gruppenes virksomhet enn den norske. Det uheldige med begrepet «selvhjelpsgrupper» er at vi kan risikere å forbinde deltakelse i 12-trinnsgrupper med en atferd som setter det individuelle selvet i sentrum, og tro at mennesker deltar i disse gruppene bare for å hjelpe seg selv. Det er imidlertid ikke det individuelle selvet som er sentrum i 12-trinnsgrupper, men gruppen eller fellesskapet.

Gjensidig hjelp og likeverd er det bærende prinsippet i 12-trinnsgrupper. I den internasjonale selvhjelpslitteraturen kalles dette prinsippet for hjelperterapiprinsippet (9). Ifølge dette prinsippet hjelper medlem- 


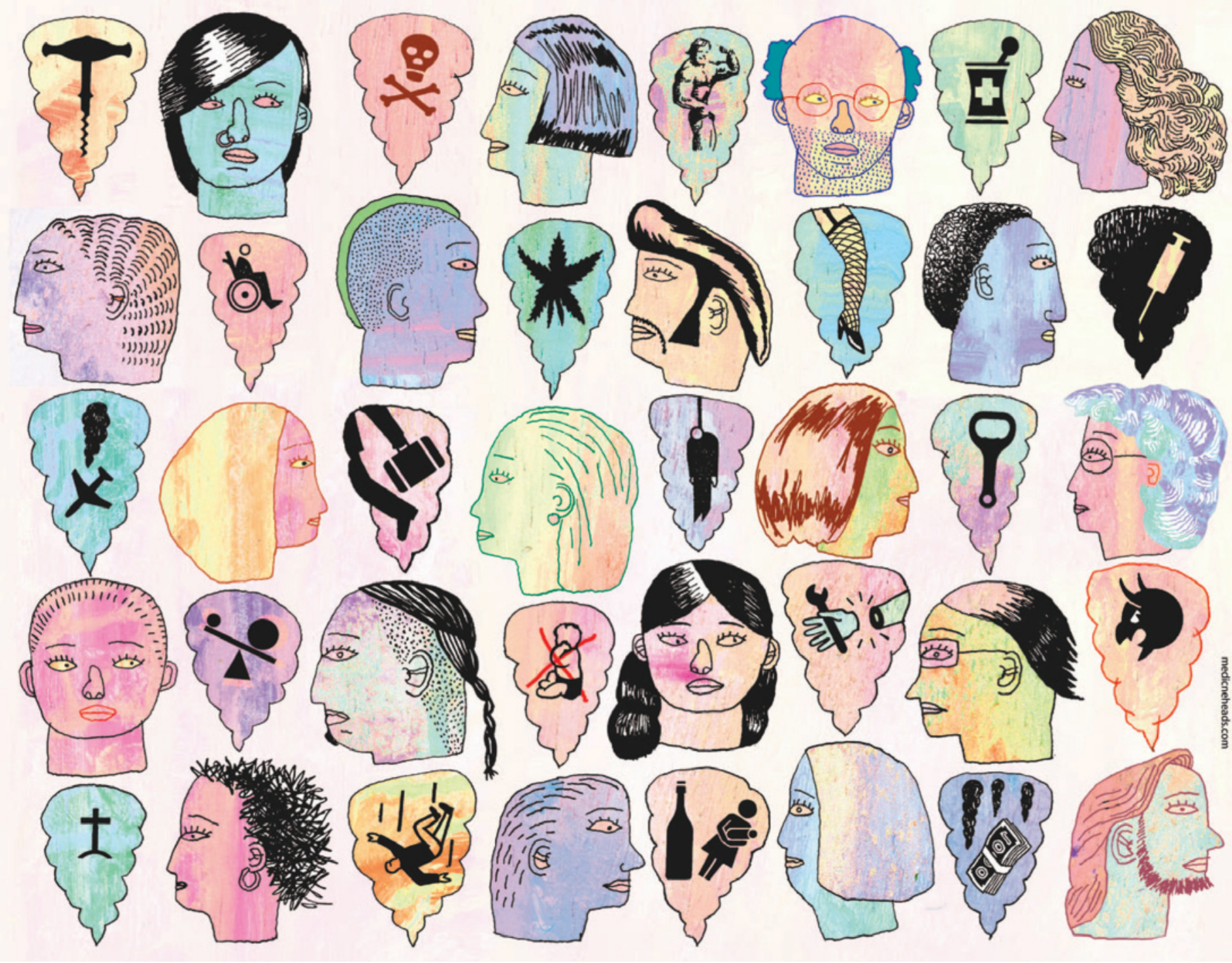

Illustrasjon Trond Nordahl/Medicineheads

mene seg selv gjennom å hjelpe andre som er i samme situasjon. Et tilsynelatende enkelt og altruistisk prinsipp, men som likevel kan være vanskelig å leve opp til for rusmiddelavhengige som er vant til å gå over lik for å skaffe seg og bruke det som oppleves som livsnødvendig, nemlig rusmidler.

Det er derfor det første av de 12 trinnene er formulert slik: «Vi innrømmet at vi var maktesløse overfor alkohol, og at vi ikke lenger kunne mestre våre liv.» Her ligger en form for kapitulasjon og erkjennelse av at man ikke lenger kan slåss mot de kreftene som rusmidlet representerer bare ved viljestyrke. Trinn 2: «Vi kom til å tro at en makt større enn oss selv kunne bringe oss tilbake til sunn fornuft.» Mange fagfolk og utenforstående har tatt dette til inntekt for at 12trinnsgrupper er religiøse organisasjoner, men hva betyr egentlig «makt større enn oss selv» i denne sammenheng?

\section{Det åndelige prinsippet i AA og NA}

12-trinns selvhjelpsgrupper har det de kaller et åndelig program, som bygger på en fundamental erkjennelse av at hver enkelt rusavhengig ikke kan klare å slåss mot rusmiddelavhengighet alene. Dette var det Bill og Bob, grunnleggerne av AA, fant ut da de møttes en gang i 1930-årene i byen Akron i USA. Begge var erklært som håpløse tilfeller av alkoholisme av fagfolk og hadde utallige institusjonsopphold bak seg. $\mathrm{Da}$ de møttes, oppdaget de til sin overraskelse at de klarte å holde seg rusfri ved å møtes og dele sine personlige historier med hverandre (10). De oppdaget med andre ord hvordan rehabilitering kan være «smittsomt» ved å praktisere gjensidig hjelp- eller hjelperterapiprinsippet.

Dette prinsippet er i dag selve navet i AAs og NAs åndelige 12-trinnsprogram. I bunn og grunn handler det om å redusere den enkelte rusavhengiges egosentrisme, som i AA oppfattes som selve roten til problemet (11). «Makten» det henvises til i flere av de 12 trinnene, har således ikke noe med religion å gjøre. Den refererer snarere til den potensielt helbredende kraften som ligger i de mellommenneskelige relasjonene tuftet på gjensidighet og likeverd.

\section{Prinsippet om hjelperterapi må brukes mer}

De offentlige og de private behandlingsmodellene egner seg ikke for alle ruspasienter. Det gjør heller ikke deltakelse i selvhjelpsgrupper. De prinsippene og metodene som anvendes i selvhjelpsgruppene, kan imidlertid også være virksomme på andre arenaer. Prinsippet om gjensidig hjelp og hjelperterapimetoden kan utnyttes mer som en del av de eksisterende behandlingsmodellene vi allerede har i Norge i dag, enten de foregår i offentlig eller i privat regi. Det bør være en oppgave for fremtidig forskning og fagutvikling å studere hvordan det offentlige hjelpeapparatet og brukerne sammen kan opprette og drive slike arenaer der de «smittsomme» og positive rehabiliteringsforholdene får anledning til å virke og utvikle seg videre, også i ruspasienters nærmiljø. Spesialisthelsetjenesten kan naturligvis ikke overta eller drive slike arenaer, men de må ha en rolle. Spørsmålet er hvilken?

Da ansvaret for rusbehandling ble lagt til spesialisthelsetjenesten i 2004, fikk rus- 
pasientene pasientrettigheter på lik linje med alle andre grupper. Det er bra, men det kan være uheldig hvis det betyr at vi er $i$ ferd med å organisere oss helt vekk fra en behandlingsform som ivaretar potensialet i erfaringsbasert kunnskap, gjensidig hjelp og hjelperterapimetoden.

\section{Trond Nergaard Bjerke (f. 1966)}

er ph.d. og forskningsleder for rusfeltet ved Fag- og forskningssenteret, Nordnorsk psykiatrisk forskningssenter, Universitetssykehuset Nord-Norge.

Ingen oppgitte interessekonflikter.

\section{Litteratur}

1. Laudet AB. The road to recovery: where are we going and how do we get there? Empirically driven conclusions and future directions for service development and research. Subst Use Misuse 2008; 43: 2001-20.

2. Vederhus JK, Kristensen $\emptyset$, Tveit $\mathrm{H}$ et al. Tolvtrinnsbaserte selvhjelpsgrupper. En ressurs i rehabiliteringen av rusmiddelavhengige. Tidsskrift for Norsk Psykologforening 2008; 45: 1268-75.

3. Vederhus JK, Hjerkinn B, Kristensen $\emptyset$. Selvhjelpsgrupper for rusmiddelavhengige. Tidsskr Nor Legeforen 2011; 131: 1204-6.

4. Litt MD, Kadden RM, Kabela-Cormier E et al. Changing network support for drinking: initial find ings from the network support project. J Consult Clin Psychol 2007; 75: 542-55.

5. Best D, Laudet A. The potential of recovery capital. RSA projects. www.thersa.org/projects/ our-projects/reports/the-potential-of-recoverycapital (30.6.2011)

6. Borkman TJ. Experiential knowledge: a new concept for the analysis of self-help Groups. Soc Serv Rev 1976; 50: 445-56.

7. Denzin NK. The alcoholic society: addiction and recovery of the self. New Brunswick: Transaction Publishers, 1987.

8. Lieberman MA. A group therapist perspective on self-help groups. Int J Group Psychother 1990; 40: 251-78.

9. Riessman $F$. The «helper» therapy principle. Soc Work 1965; 10: 27-32

10. Alcoholics Anonymous. Twelve steps and twelve traditions. New York: Alcoholics Anonymous World Services, 1981.

11. Pagano ME, Post SG, Johnson SM. Alcoholic Anonymous-related helping and the helper therapy principle. Alcohol Treat Q 2011; 29: 23-34.

Mottatt 6.7. 2011, første revisjon innsendt 11.10 2011, godkjent 27.10. 2011. Medisinsk redaktør

Petter Gjersvik. 